УДК 37

DOI $10.21661 / \mathrm{r}-472122$

\title{
Н.Н. Крамаренко
}

\section{АППЛИКАЦИЯ КАК СРЕДСТВО РАЗВИТИЯ ТВОРЧЕСКИХ СПОСОБНОСТЕЙ СТАРШЕГО ДОШКОЛЬНОГО ВОЗРАСТА}

Аннотация: в данной статье рассказывается о развитии творческих способностей у детей старшего дошкольного возраста. В качестве средства развития творческих способностей у дошкольников автором используется аппликачия, способствующая развитию эмоциональной отзывчивости, развитию воображения, аккуратности, трудолюбия у ребенка.

Ключевые слова: творчество, творческие способности, аппликаџия, старшие дошкольники.

\section{N.N. Kramarenko}

\section{APPLIQUE WORK AS A MEAN OF CREATIVE ABILITIES DEVELOPMENT OF OLDER PRESCHOOL AGE}

Abstract: the article is devoted to the development of creative abilities of senior pre-school age children. The author uses as a method of development of creative abilities of senior pre-school age children to promote development of the emotional responsiveness, imagination, neatness and diligence forming among children.

Keywords: creativity, creative abilities, applique, senior pre-school age children.

Доказано, что дошкольный возраст является сензитивным и наиболее благоприятным для развития воображения, психических процессов, и развития образного мышления, которые составляют основу творческой деятельности ребенка. Вследствие этого, становление детского творчества считается одной из ключевых задач дошкольного воспитания, как отмечают Т.С. Комарова, Е.А. Флерина, Г.Г. Григорьева, И.А. Лыкова, С.В. Погодина и др.

В современной педагогической науке вопрос развития детского творчества раскрывается сейчас с новых позиций раскрытия субъектности и творчества 
дошкольника. По мнению С.В. Погодиной, «детское творчество все время находится в движении, оно постоянно меняется, так как меняется опыт ребенка, его отношение к окружающему миру и искусству» [3]. Для этого педагоги должны искать новые приемы и методы, позволяющие развивать творческий потенциал ребенка, способствующие возникновению новых замыслов. Поэтому проблема развития детского творчества становится все более актуальной.

В дошкольных организациях, в основном, занятия направлены на формирование изобразительных знаний, умений и навыков, и по-прежнему носят строгий дидактический характер, зачастую не интегрированы в образовательный процесс или имеют лишь характер заполнения свободного времени детей. А. Мелик-Пашаев считает, что «целью обучения детей художественной деятельности должно быть развитие воображения, эстетического отношения к миру. Самое успешное развитие знаний, умений, навыков, «служебных» качеств не приведет к творческому развитию личности дошкольника» [3]. Эту мысль поддерживает и Мюллер Р., по мнению автора «в основу комплекса знаний, умений и навыков должны быть положены изобразительные умения и способность наблюдать, сопереживать увиденному [3].

В настоящее время, проблема развития детского творчества остается актуальной несмотря на то, что проблема изучена достаточно широко, детское творчество требует более точечного изучения, в частности возможностей аппликации в развитии творческих способностей детей. В особенности возможностей развития таких граней творческих способностей как установление новых связей, нетрадиционного взгляда на соотношение пропорций, использование и отражение пространства в детской аппликации, создание сюжета с разнообразного ракурса, изображение персонажей с помощью разных геометрических фигур, линий, введения неклассических техник аппликации для облегчения реализации оригинального замысла ребенка в сюжете.

В образовательных программах дошкольного образования задачи аппликации направлены на развитие композиционного умения, соблюдение пропорциональности и овладению технических навыков. О таких показателях творчества 
как оригинальность, гибкость, продуктивность изображения в программах не говорится, хотя они являются важными критериями творчества в сюжетном рисовании.

Дошкольный возраст - это возраст наиболее активной аппликационной деятельности, поэтому аппликация как способ отражения и преобразования окружающей дошкольника действительности должен быть не только глубоко изучен, но и использован в максимальной мере.

Цель нашего исследования: изучение и экспериментальная апробация педагогических условий развития творческих способностей детей старшего дошкольного возраста.

В основу исследования положена гипотеза о том, что развитие творческих способностей старшего дошкольного возраста по средствам аппликации будет более эффективным, при реализации следующих педагогических условий:

- подбор содержания изобразительной деятельности, раскрывающей возможности развития творческих способностей в аппликации, в том числе с использованием неклассических техник аппликации;

- обогащение образовательной среды разнообразными аппликационными материалами,

- организация работы с педагогами, направленной на повышение их компетентности в вопросах развития творческих способностей детей в аппликации.

Для выявления уровня развития творческих способностей мы подобрали методики Э.П. Торренса «Незаконченный рисунок» и «Дорисовывание». Для выявления уровня развития творческих способностей у детей старшего дошкольного возрастав аппликации, на основании выделенных нами критериев творчества, мы разработали методику «Оценка сформированной творческих способностей в аппликации».

Результаты показали, что творческие способности детей старшего дошкольного возраста необходимо развивать и наиболее эффективными средствами развития могут выступать занятия по аппликации с использованием неклассических техник аппликации, способствующих развитию воображения. 
Для развития творческих способностей детей старшего дошкольного возраста в аппликации нами был организован формирующий эксперимент. В ходе него мы использовали комплекс развивающих занятий, предполагающих разнообразие материалов и инструментов для создания композиции. Использовали игры и неклассические техники аппликации, которые способствуют развитию воображения и творческого мышления. Организация работы осуществлялась поэтапно, также осуществлялось взаимодействие с педагогами и родителями.

Результаты контрольного эксперимента показали, что в экспериментальной группе количество детей с высоким уровнем на контрольном этапе эксперимента увеличилось на 10\% (2 ребенка), количество детей со средним уровнем повысилось на 30\% (6 детей), низкий уровень уменьшился на 40\% (8 детей).

Таким образом, результаты исследования показали, что созданные нами педагогические условия развития творческих способностей в аппликации детей старшего дошкольного возраста является эффективным. Гипотеза исследования верна.

\section{Список литературь}

1. Арапова С.В. Обучение изобразительному искусству. Интеграция художественного и логического [Текст] / С.В. Арапова. - СПб.: КАРО, 2014.

2. Борисова Е. Развиваем творческие способности [Текст] / Е. Борисова // Дошкольное воспитание. - 2009. - №2. - С. 52-54.

3. Погодина С.В. Теория и методика детского изобразительного творчества [Текст] / С.В. Погодина. - М.: Академия, 2011. - 352 с.

\section{References}

1. Arapova, S.V. (2014). Obuchenie izobrazitel'nomu iskusstvu. Integratsiia khudozhestvennogo i logicheskogo. SPb.: KARO.

2. Borisova, E. (2009). Razvivaem tvorcheskie sposobnosti. Doshkol'noe vospitanie, 2, 52-54.

3. Pogodina, S.V. (2011). Teoriia i metodika detskogo izobrazitel'nogo tvorchestva., 352. M.: Akademiia. 
Крамаренко Наталия Николаевна - студентка Педагогического института ФГБОУ ВО «Иркутский государственный университет», Россия, Иркутск.

Kramarenko Nataliia Nikolaevna - student at the Pedagogical institute of "Irkutsk State University", Russia, Irkutsk. 